\title{
Separation and Concentration of Traces of Metals by the Use of Copper Sulfide as a Collector
}

\author{
Hitoshi Kamada, Yûsuke Ujinira and Katsuaki Fukuda \\ Faculty of Engineering, University of Tokyo \\ Received January 21, 1965
}

\begin{abstract}
A study is described for the separation and concentration of various metals from an aqueous solution by carrier precipitation with copper sulfide using radioisotope as a tracer. One milligram of copper (II) and $0.06 \sim 0.1 \mathrm{ml}$ of $1 M$ sodium sulfide solution are added to $20 \sim 50 \mathrm{ml}$ of solution containing $\mu_{\mathrm{g}}$ quantities of metals, and the distribution of $\mu_{\mathrm{g}}$ amounts of metal is investigated by measuring the radioactivity in liquid phase or solid phase (precipitate).

Gold, silver, mercury, platinum and copper are collected completely from $0.1 \sim 1.0 \mathrm{~N}$ hydrochloric acid solution, whereas cobalt, thallium and zinc are retained in solution. $>90 \%$.

The increase of $\mathrm{pH}$ above 9.0, however, enhances the recovery of cobalt and zinc up to

The recovery is not affected by the difference of carrier or the method or rate of precipitation. Though the presence of chloride ion $(<25 \%)$ does not decrease the recovery, the presence of complexing reagents of trace metals diminishes the recovery remarkably.

The treatment of copper sulfide precipitates is demonstrated by several methods. This procedure has effectively been applied to the separation and concentration of traces of gold, silver or mercury in copper, lead, zinc, nickel and manganese.
\end{abstract}

Since sulfide ion reacts with various cations to form sparingly soluble sulfide, it has long been used as an excellent precipitant for many kinds of metals.

This has been shown to be the case of the precipitation or separation of gold, silver, platinum, mercury, copper, lead, arsenic, antimony, tin, etc from the solution of diluted sulfuric or hydrochloric acid solution, and that of iron, cobalt, nickel manganese, zinc, etc from an alkaline solution ${ }^{11}$.

However, it is quite difficult to obtain complete precipitation or quantitative separation of sulfides when the amounts of elements are 0.1 $\mathrm{mg}$ or less (below $10^{-5} \mathrm{M}$ in concentration).

To overcome this inconvenience or to utilize sulfide precipitation for the separation and concentration of trace amounts of metals, other element is added as a carrier for a precipitation.

Onishi and Sandell ${ }^{2}$ enriched $0 \sim 10 \mu \mathrm{g}$ of antimony in rocks and biomaterials with copper sulfide from $0.5 \mathrm{~N}$ sulfuric acid-tartaric acid solution, Hubbard ${ }^{3)}$ concentrated $1 \sim 500 \mu \mathrm{g}$ of bismuth in biomaterials with copper sulfide, Ansbacher and Remington ${ }^{4}$ adsorbed $50 \mu \mathrm{g}$ of copper on sulfur produced in situ, Fisher and
$\mathrm{Keim}^{5)}$ separated $100 \mu \mathrm{g}$ of germanium in silicate from $6 \mathrm{~N}$ sulfuric acid by the use of mercury as a carrier, Yokosuka ${ }^{6}$ concentrated ppm contents of lead in nickel by fractionally precipitating the matrix as sulfide, Dowson and Rees ${ }^{\text {7) }}$ enriched lead in creta with copper sulfide, Ballard and Thornton ${ }^{8)}$ gathered mercury on asbestos impregnated with cadmium sulfide, Bufatin Zaidel and Kaliteevskii ${ }^{9)}$ separated 100 $\mu \mathrm{g}$ of platinum and palladium in uranium using copper sulfide as a collector, Sugihara ${ }^{10}$ ) collected $0 \sim 20 \mu \mathrm{g}$ of silver in hot spring water with arsenic sulfide, Babko and Marchenko ${ }^{11)}$ entrained ppm range of bismuth, cadmium, lead and zinc in molybdenum-nickel or tungstennickel from alkaline solution, and Degtyarenko, Libina and Miller ${ }^{12)}$ carried down $\mu \mathrm{g} / l$ of copper, cobalt, lead and zinc in natural water with cadmium sulfide. Other attempts are also published ${ }^{13) \sim 17)}$.

Though many investigations have appeared, little informations are yet available for the carrier precipitation of microgram quantities of metals. Furthermore, any extensive study has not been made on the mechanism of carrying process. 
The present work was undertaken to obtain some knowledge concerning the mechanism and the possibility of increasing the selectivity for separation and concentration of microgram amount of elements using copper sulfide as a collector.

To measure the distribution of traces of elements between solid phase and liquid phase accurately, appropriate radioactive tracers are used except for platinum and palladium.

The information derived from experiments was applied to the isolation of traces of gold, silver or mercury in high purity metal compounds.

\section{Experimental}

\section{Reagents}

Carrier solution : $1 \mathrm{mg}-\mathrm{Cu} / \mathrm{ml}$ solution was prepared by dissolving reagent grade copper sulfate or copper nitrate in water.

Sodium sulfide: $1.0 \mathrm{M}$ solution was prepared by dissolving reagent grade sodium sulfide in water.

Buffer solutions : $\mathrm{pH} 3.5 \sim 6.0$ buffer solutions were prepared by mixing $0.1 \mathrm{~N}$ acetic acid with the required quantities of $0.1 \mathrm{~N}$ sodium hydroxide. pH7.0 10.0 buffer solutions were prepared by mixing $0.1 \mathrm{~N}$ boric acid with the required quantities of $0.1 \mathrm{~N}$ sodium hydroxide.

Standard radioactive solutions were prepared by adding proper radioisotope to the standard solution of the element to be investigated of the concentration of $1.0 \sim 5.0 \mu \mathrm{g} / \mathrm{ml}$.

Experiments concerning platinum were proceeded in the same as way that of our previous work $^{18)}$. Experiments concerning palladium were proceeded in the same way as that of our previous work ${ }^{19)}$.

Tracers: ${ }^{110 \mathrm{~m}} \mathrm{Ag},{ }^{203} \mathrm{Hg}$ and ${ }^{65} \mathrm{Zn}$ were procured commercially from Oak Ridge National Laboratory (USA). ${ }^{198} \mathrm{Au},{ }^{60} \mathrm{Co},{ }^{124} \mathrm{Sb}$ and ${ }^{204} \mathrm{Tl}$ were obtained commercially from the Radiochemical Centre (Amersham, England). ${ }^{76} \mathrm{As},{ }^{64} \mathrm{Cu}$ and ${ }^{142} \mathrm{Pr}$ were prepared in the JRR-1 by irradiating neutron against arsenic trioxide, copper nitrate and praseodymium oxide respectively.

The radioactivity was measured by a welltype scintillation counter and an end-windowtype Geiger-Müller counter.

The radiochemical purity of radioactivity was examined either by $\gamma$-ray spectrometry or by the measurement of half-life, or by the study of chemical behavior.

Method. The desired volume of standard radioactive solution and $1 \mathrm{~m} l$ of copper solution were placed in a $50 \mathrm{ml}$ Terex beaker, and diluted to $25 \mathrm{ml}$ with $0.1 \mathrm{~N}$ hydrochloric acid, adjusting $\mathrm{pH}$ with buffer solution if necessary. Then $0.06 \sim 0.1 \mathrm{~m} l$ of sodium sulfide solution was added to the solution, heated at about $80^{\circ} \mathrm{C}$ for 10 minutes. After cooling to room temperature, th precipitate was filtered off through a filter paper (Toyo Roshi No. 5C, $\phi 5.5 \mathrm{~cm}$ ) and $1 \mathrm{ml}$ of the filtrate (or the precipitate together with the filter paper used) was transfered in a test tube, and the radioactivity was measured.

The recoveries of trace elements were obtained by comparing the radioactivity of specimen with that of standard radioactive solution.

The precipitate and the filter paper for platinum and palladium were ignited, and proceeded as was indicated in the previous papers $^{17), 18)}$.

\section{Results and Discussion}

The recovery of the microgram quantities of metals - gold, mercury, silver, palladium, arsenic, antimony, cobalt, thallium and zinc -

Table 1 Recovery of various elements by carrier precipitation with copper sulfide

(From $0.1 N$ hydrochloric acid solution)

\begin{tabular}{cc|c|c}
\hline $\begin{array}{c}\text { Element taken } \\
(\mu \mathrm{g} / 25 \mathrm{~m} l)\end{array}$ & Tracer & $\begin{array}{c}\text { Recovery } \\
(\%)\end{array}$ \\
\hline $\mathrm{Cu}$ & 5 & $\mathrm{Cu}-64$ & $98^{*}$ \\
$\mathrm{Ag}$ & 5 & $\mathrm{Ag}-110 \mathrm{~m}$ & $96 \sim 100$ \\
$\mathrm{Au}$ & $0.1 \sim 100$ & $\mathrm{Au}-198$ & 98 \\
$\mathrm{Zn}$ & $0.1 \sim 100$ & $\mathrm{Zn}-65$ & $<2$ \\
$\mathrm{Hg}$ & 5 & $\mathrm{Hg}-203$ & 98 \\
$\mathrm{Tl}$ & 5 & $\mathrm{Tl}-204$ & $<2$ \\
$\mathrm{As}$ & 5 & $\mathrm{As}-76$ & $74 \sim 94$ \\
$\mathrm{Sb}$ & 5 & $\mathrm{Sb}-124$ & 86 \\
$\mathrm{Co}$ & $0.1 \sim 100$ & Co-60 & $<2$ \\
$\mathrm{Pd}$ & 5 & Colorimetry & $\simeq 90$ \\
$\mathrm{Pt}$ & 5 & Colorimetry & $\simeq 95$ \\
\hline
\end{tabular}

* Tellurium was used as a carrier.

** Low recovery partially owing to the loss during the colorimetrical procedure.

from $0.1 \mathrm{~N}$ hydrochloric acid solution with 


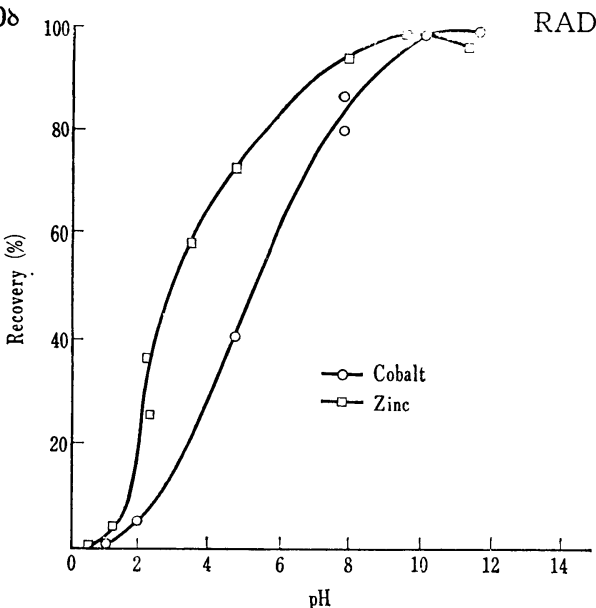

Fig. 1 Effect of $\mathrm{pH}$ on the carrier precipitation of cobalt and zinc.

copper sulfide is shown in Table 1. In this experiment, the increase of acidity to $1 \mathrm{~N}$ or the difference of acidic medium - nitric acid or sulfuric acid shows little difference in the percentage of recovery. Though cobalt and zinc are not carried down from acidic media, the percentage of recoveries increase with $\mathrm{pH}$ and almost quantitative above $\mathrm{pH} 9$, as is shown in Fig. 1.

The difference of the initial amounts of trace metals shows little effects on the recoveries of traces, as is shown in Table 2.

Table 2 Effect of initial amounts of traces on carrier precipitation

\begin{tabular}{|c|c|c|c|c|}
\hline Element & \multicolumn{4}{|c|}{ Recovery $(\%)$} \\
\hline & 0.1 & 1.0 & 10.0 & $100.0^{*}$ \\
\hline Gold $\{1 N \mathrm{HCl}$ & 一 & 98 & - & 100 \\
\hline$(\mathrm{pH} 8 \sim 11$ & - & 99 & - & $90 \sim 80$ \\
\hline Cobalt $\mathrm{pH} 10$ & 95 & 95 & - & 93 \\
\hline Zinc $\mathrm{pH} 10$ & 93 & 95 & 95 & 89 \\
\hline
\end{tabular}

* Quantity of traces $(\mu \mathrm{g} / \mathrm{m} l)$

From the results of Fig.1 and Table 2, the formation of metal sulfide of trace metal is conjectured.

To assure high recovery, the similarity in ionic radius between carrier and traces has been proposed by Sandell ${ }^{20)}$ and Pickett and Hankins ${ }^{21)}$.

The effect of carrier was investigated by substituting copper to other elements. The results are shown in Table 3, which indicates the function of carrier or collector to be scavenging of metal sulfide colloid, and the relative ionic radii has little effect on the carrier pre-
Table 3 Effect of collector on carrier precipitation

\begin{tabular}{|c|c|c|}
\hline $\begin{array}{l}\text { Element taken } \\
(\mu \mathrm{g} / 25 \mathrm{~m} l)\end{array}$ & $\begin{array}{l}\text { Carrier } \\
(\mathrm{mg})\end{array}$ & $\begin{array}{c}\text { Recovery } \\
(\%)\end{array}$ \\
\hline \multirow[t]{2}{*}{$\mathrm{Cu}(0.72) 1^{*}$} & $\mathrm{Cu} \quad(0.72) \quad 1$ & 100 \\
\hline & $\mathrm{Te} \quad(0.70) 1$ & 98 \\
\hline \multirow[t]{3}{*}{$\mathrm{Ag}(0.85) 2^{*}$} & $\mathrm{Cu} \quad(0.72) \quad 1$ & 96 \\
\hline & As $(0.58) 2$ & 99 \\
\hline & $\mathrm{Hg}(1.10) 2$ & 100 \\
\hline \multirow[t]{4}{*}{$\mathrm{Au}(0.85) 1^{*}$} & $\mathrm{Cu} \quad(0.72) \quad 1$ & 98 \\
\hline & As $(0.58) 2$ & 100 \\
\hline & $\mathrm{Hg}(1.10) 2$ & 100 \\
\hline & $\mathrm{Pb} \quad(1.20) 4$ & 99 \\
\hline \multirow[t]{4}{*}{ Co $(0.72) 1^{* *}$} & $\mathrm{Cu}(0.72) \quad 1$ & 95 \\
\hline & $\mathrm{Hg}(1.10) 1$ & 96 \\
\hline & $\mathrm{Ni} \quad(0.69) 1$ & 91 \\
\hline & $\mathrm{Fe} \quad(0.74) \quad 1$ & 90 \\
\hline \multirow[t]{4}{*}{$\operatorname{Zn}(0.74) 1^{* *}$} & $\mathrm{Cu} \quad(0.72) \quad 1$ & 95 \\
\hline & $\mathrm{Hg}(1.10) \quad 1$ & 96 \\
\hline & $\mathrm{Ni} \quad(0.69) 1$ & 91 \\
\hline & $\mathrm{Fe}(0.74) 1$ & 95 \\
\hline
\end{tabular}

( ) Ionic radii, $\AA$

* $0.1 N$ hydrochloric acid

** $\mathrm{pH} 10 \pm 0.2$

cipitation by sulfides.

The effects of method of precipitating copper sulfide are also studied by comparing the results obtained with the three precipitating methods - ordinary hydrogen sulfide method, ordinary sodium sulfide method and homogeneous precipitation method by thioacetamide ${ }^{22}$.

Table 4 Effect of different methods of precipitation on carrier precipitation

\begin{tabular}{ll|r|r|r}
\hline \multirow{2}{*}{$\begin{array}{c}\text { Element taken } \\
(\mu \mathrm{g} / 25 \mathrm{~m} l)\end{array}$} & \multicolumn{3}{|c}{ Recovery $(\%)$} \\
\cline { 2 - 5 } & $\mathrm{Na}_{2} \mathrm{~S}$ & $\mathrm{H}_{2} \mathrm{~S}^{*}$ & $\mathrm{CH}_{3} \mathrm{CSNH}_{2}$ \\
\hline $\mathrm{Cu}$ & 2 & 100 & 99 & - \\
$\mathrm{Ag}$ & 4 & 99 & 98 & 93 \\
$\mathrm{Au}$ & 5 & 100 & 98 & 99 \\
$\mathrm{Pt}$ & 5 & 100 & 100 & - \\
\hline
\end{tabular}

* $\mathrm{H}_{2} \mathrm{~S}$ gas was passed through for $10 \mathrm{~min}$.

As is shown in Table 4, the difference of precipitation method or the rate of precipitation has little effect on the recovery of traces.

The influence of co-existing material upon the percentage of recovery was investigated. 
Though the presence of chloride ion up to $25 \%$ shows little effect on the carrying down of copper*, silver, gold and platinum (Table 5), the existence of complexing reagents gives a considerable influence upon the percent of carrying down of traces.

Table 5 Effect of chloride ion on carrier precipitation

\begin{tabular}{c|c|c|c|c}
\hline \multirow{2}{*}{$\mathrm{NaCl}(\%)$} & \multicolumn{4}{|c}{ Recovery $(\%)$} \\
& \multicolumn{3}{|c|}{ Element taken $5 \mu \mathrm{g} / 25 \mathrm{~m} l)$} \\
\cline { 2 - 5 } & $\mathrm{Cu}$ & $\mathrm{Ag}$ & $\mathrm{Au}$ & $\mathrm{Pt}$ \\
\hline 25 & 98 & 96 & 98 & 95 \\
20 & 98 & 98 & - & 95 \\
10 & 98 & 98 & - & 95 \\
5 & 98 & 98 & 98 & 95 \\
\hline
\end{tabular}

The effects of iodide ion, cyanide ion and EDTA upon the carrier precipitation of gold, zinc and cobalt are shown in Fig. 2 at the function of concentration of complexing reagents.

The decrease in percent of carrying down of traces with an increase of complexing reagents'
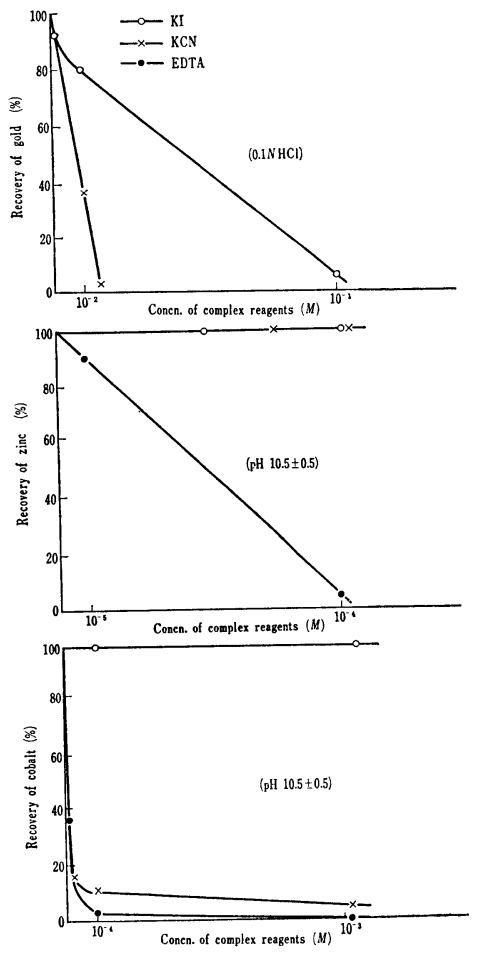

Fig. 2 Influence of complexing reagents on 1:1tries nrecipitation. concentration is explained by the formation of iodo-, cyano-or EDTA complexes.

This phenomenon may successfully be applied for the selective separation of traces by carrier precipitation with copper sulfide.

Table 6 Treatment of precipitate

\begin{tabular}{lc|c|c|c}
\hline $\begin{array}{c}\text { Element } \\
\text { taken } \\
(\mu \mathrm{g} / 25 \mathrm{~m} l)\end{array}$ & $\begin{array}{c}\text { Conditions of } \\
\text { precipitation }\end{array}$ & $\begin{array}{c}\text { Recovery }(\%) \\
\text { Dissolving } \\
\text { method }\end{array}$ & $\begin{array}{c}\text { Dry ashing } \\
\text { method }\end{array}$ \\
\hline $\mathrm{Ag}$ & 5 & $0.1 N \mathrm{HNO}_{3}$ & - & 48 \\
& & $\begin{array}{l}0.1 N \mathrm{HNO}_{3} \\
20 \% \mathrm{NaCl}^{2}\end{array}$ & - & 38 \\
$\mathrm{Au}$ & 1 & $0.1 N \mathrm{HCl}$ & 30 & 93 \\
$\mathrm{Pt}$ & 5 & $1 N \mathrm{HCl}$ & 20 & 95 \\
$\mathrm{Hg}$ & 5 & $0.1 N \mathrm{HNO}$ & - & 0 \\
$\mathrm{Zn}$ & 1 & $\mathrm{pH} \mathrm{11}$ & - & 43 \\
$\mathrm{Pd}$ & 5 & $1 N \mathrm{HCl}$ & 40 & - \\
$\mathrm{As}$ & 5 & $1 N \mathrm{HCl}$ & - & 24 \\
$\mathrm{Co}$ & 1 & $\mathrm{pH} 11$ & - & 97 \\
\hline
\end{tabular}

Sulfides are hard to be dissolved in acids, such as nitric acid and hydrochloric acid, and residues are subjected to be adsorbed on filter paper or glass apparatus. Table 6 shows the results of the study of the treatment of precipitates, mainly by dryashing procedure. The decomposition of the precipitate and the filter paper used was attained by burning them in a casserole and the ashes were dissolved in aqua regia. The recoveries of cobalt, platinum and gold are quantitative, whereas those of silver, zinc and palladium are not sufficient, while mercury and arsenic are completely lost. It is conjectured that silver and palladium were adsorbed on the inner wall of the casserole, and zinc, mercury and arsenic were evaporated away in the process of dryashing to overcome these inconvenience and to make utmost of a carrier precipitation with copper sulfide, this separation method may be most widely and effectively combined with the instrumental determination technique such as emission spectrometry or X-ray method.

Carrier precipitation method using sodium sulfide as a precipitating agent was applied to the separation and concentration of traces

* Carrier $\sim 1 \mathrm{mg}$ of tellurium. 
of silver, gold and mercury in a large excess of copper, lead, manganese, nickel and zinc. Satisfactory results were obtained, as is shown in Table 7. In the case of copper and lead, matrices themselves were fractionally precipitated to work as a carrier. This method may offer certain advantages over conventional method in simplicity and higher reproducibility.

Table 7 Separation of trace elements

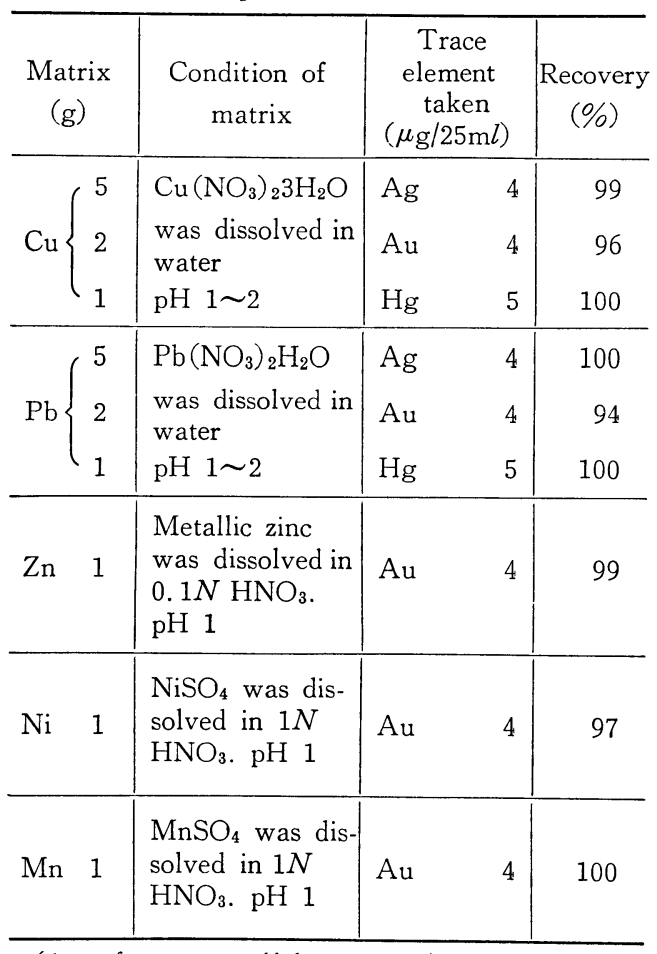

( $1 \mathrm{mg}$ of copper was added as a carrier.)

\section{References}

1) F. P. Treadwell : "Analytical Chemistry", 1, John Willey and Sons, Inc., New York (1949)

2) H. Onishi and E. B. Sandell : Anal. Chim. Acta, 11, 444 (1954)

3) D. M. Hubbard : Ind. Eng. Chem, Anal. Ed., 11, 343 (1939)
4) S. Ansbacher, R. E. Remington and F. B. Culp: Ind. Eng. Chem., Anal. Ed., 8, 314 (1931)

5) W. Fisher and H. Keim: Z. anal. Chem., 128, 443 (1948)

6) S. Yokosuka: Japan Analyst, 4, 100 (1955)

7) E. C. Dowson and A. Rees: Analyst, 71, 417 (1946)

8) A. E. Ballard and C. D. W. Thornton: Ind. Eng. Chem., Anal. Ed., 13, 893 (1941)

9) O. I. Bufatin, A. N. Zaidel and N. I. Kaliteevskii : Zhur. Anal. Khim., 13,116(1958)

10) K. Sugihara: J. Chem. Soc. Japan (Nippon Kagaku Zasshi), 81, 77 (1960)

11) A. K. Babko and P. V. Marchenko: Zavodsk-, aya Lab., 23, 1278 (1957); Chem. Abstr. 53, 3997 a (1959)

12) A.P. Degtyarenko, R. I. Libina and A.D. Miller: Chem. Abstr., 54, 20024e (1960)

13) L. T. Fairfall and L. Prodan: J. Am. Chem. Soc., 53, 1321 (1931)

14) T. Ernst and H. Hörman: Z. anal. Chem., 111, 425 (1937 1938)

15) K. Süpfel and R.Werner : Mikrochemie, 36/37, 866 (1951)

16) F. R. Williams and J. Whitehead: $J . A p p l$. Chem., 2, 213 (1952)

17) I. Yu. Sokolov, V. A. Polyakov and V.V. Lushnikov: Chem. Abstr., 53, 3997a (1959)

18) Y. Ujihira and S.Hirano: Bull. Chem. Soc. Japan, 37, 67 (1964)

19) Y. Ujihira: Talanta (under contribution)

20) E. B. Sandell: "Colorimetric Determination of Traces of Metals". p.32, Interscience Publishers Inc., New York (1959)

21) E.E.Pickett and B.E. Hankins: Anal. Chem., 30, 47 (1958)

22) The Japan Society for Analytical Chemistry Ed., "Separation with Organic Reagents in Analysis (Yuki Shiyaku ni yoru Bunri Bunseki Ho" Vol. 1, p.257, Kyoritsu Shuppan, Tokyo (1961) 
要旨

\title{
硫化銅を捕集剈として用いる微量元素の分離濃縮
}

\author{
鎌田 仁, 氏平祐輔, 福田克顕 \\ 東京大学工学部工業化学科教室
}

水溶液中に数 $\mu \mathrm{g} / 50 \mathrm{~m} l$ で存在する金, 銀, 銅, 水銀, 严鉛, タリウム, ヒ素, アンチモン, コ バルト, パラジゥムおよび白金を硫化銅（Cu-1 mg）を捕集剂として用いて分離濃縮するさいの基 礎的資料を集めた。各種標準放射性溶液をビーカーにとり, 銅溶液を加え硫化ナトリウム溶液を添 加し，生じた沈殿をロ別してロ液または沈殿の放射能強度を井戸型シンチレーション・カウンター で測定し，同時に測定した標準の放射能と比較して共沈率を求めた，白金およびパラジウムは比色 法によった。

$1 N$ 硝酸酸性で金, 銀, 銅, 水銀, 白金, パラジウム, ヒ素は完全に, また $\mathrm{pH} 9$ で亜鉛, コバ ルトが定量的に共沈した。銅以外の担体によっても共沈率は変わらなかった。塩素イオンが共存し ても共沈率に変化はなかったが錯化剤の共存によって共沈率は低下した。硫化物沈殿の方法として チオアセトアミドによる均質沈殿法を用いても共沈率に変化が認められなかった。沈殿の処理法と してはしゃく熱灰化の方法によった。応用例として銅, 鉛, 亚鉛, ニッケル, マンガン中の微量金, 銀，水銀を分離濃縮して満足な結果を得た。 